\title{
ALEITAMENTO MATERNO E HÁBITOS NOCIVOS E A SUA RELAÇÃO COM AS ALTERAÇÕES OCLUSAIS
}

Aguinaldo Coelho de FARIAS; Maria Carolina Gonçalves CARNASCIALI

O presente trabalho irá fazer uma revisão sobre a relação da importância do aleitamento materno com a correta formação do sistema mastigatório. Os movimentos de sucção durante o aleitamento natural são importantes para o desenvolvimento dos órgãos fonoarticulatórios (lábios, língua, mandíbula, maxila, bochechas, palato mole e duro, soalho da boca, musculatura oral e arcadas dentárias) quanto à mobilidade, força, postura e desenvolvimento das funções de respiração, mastigação, deglutição e articulação dos sons da fala. Os bebês aleitados de forma natural executam um intenso trabalho muscular ao sugar o seio materno, ficando a musculatura peribucal fatigada, o que faz com que a criança não necessite da sucção de chupeta, dedo ou outro objeto. A mamadeira promove apenas a ação dos músculos bucinadores e orbicular da boca, não estimulando outros importantes músculos da mastigação nem o crescimento mandibular, pois não requer movimentos de protrusão e retração da mandíbula, levando à formação de arcadas estreitas e a falta de espaço para dentes e língua. Hábitos de sucção não nutritivos levam a alterações no sistema estomatognático como: retrognatismo mandibular, prognatismo maxilar, mordida aberta anterior, musculatura labial superior hipotônica, musculatura labial inferior hipertônica, atresia do palato e do arco superior, interposição de língua e respiração bucal. 